\title{
PERSPECTIVE OF SUSTAINABLE DEVELOPMENT IN POST-PANDEMIC WORLD: SURVEILLANCE CAPITALISM AND HOPES
}

\author{
ŁUKASZ RĄB ${ }^{1}$ \& KAROLINA KETTLER ${ }^{2}$ \\ ${ }^{1}$ The Maria Grzegorzewska University, Department of Philosophy and Sociology, Szczęśliwicka 40, 02- \\ 353 Warsaw, Poland. ORCID: 0000-0002-9932-5328, Email: 1rab@aps.edu.pl \\ ${ }^{2}$ Silesian University of Technology, Department of Applied Social Sciences, Roosevelta 26, 41-800 Za- \\ brze, Poland. ORCID: 0000-0001-9536-1375, Email: karolina.alina.kettler@gmail.com
}

\begin{abstract}
The current coronavirus pandemic is not only a health/healthcare crisis, it will also greatly influence other spheres of life, including social relations, the shape of economy and working models, and natural environment. Sustainable development that relies on the previously mentioned pillars (economy, society, environment) is going to be strongly affected by the virus outbreak. There is a threat that the process of recovering from the corona crisis will accelerate and legitimize the dynamics of surveillance capitalism. A really interesting case is going to be the labor world, where thanks to modern technologies, suppression of personal freedoms and triumph of total surveillance might be particularly easy. However, good scenarios are also plausible. The first 21st century pandemic of that scale may force societies to redefine their current modus operandi and shift capitalism into a more sustainable, humanistic model. KEYWORDS: sustainable development, surveillance capitalism, post-pandemic world, utopia, work, humanistic management
\end{abstract}




\section{INTRODUCTION}

The multi-faceted concept of sustainable development encompasses a multitude of socio-economic-natural factors that affect the implementation of its principled objectives to varying degrees. The basic concept of sustainable development is to maintain a balance between economic, environmental and social factors. Although these aspects are well known and diagnosed, still many of them affect sustainable development in a negative way. Therefore, a new element that has not been taken into account so far may lead to a regression or even halt the implementation of sustainable development. Coronavirus and the current pandemic constitute a factor of this kind. Assuming that sooner or later the plague will pass, the question has to be asked: what impact will it have on social and economic relations and nature, and thus how will sustainable development goals be achieved in the post-pandemic world, and will it be possible at all?

In our analysis we will have a closer look on the concept of surveillance capitalism, and on how it, in the post-pandemic reality, will influence the way we work. Obviously, the corona-crisis will highly change the work models; and it is not only because of the remote work, which had been popular before, however, on much smaller scale. It is a major chance but also a significant threat for the labor world - we will either achieve what Rutger Bregman stated in his Utopia for Realists, or quite the opposite, the post-pandemic workplaces will turn into panopticons.

\section{THE PANDEMIC AND SURVEILLANCE CAPITALISM}

Like the climate change, coronavirus does not discriminate against anyone, it is unbelievably democratic. Social class, gender, race - all these are not important, however, for some people this pandemic is more dangerous than for others. Not because they were in the wrong place at the wrong time, but because the pandemic is managed by capitalism combined with human fear of death. The dynamics of capitalism tends to capitalize global suffering, the fear of death triggers people's irrational beliefs and actions that are harmful to society, and all this leads to the introduction of new forms of surveillance, to the rule of surveillance capitalism. The current pandemic is to surveillance capitalism what until recently the figure of "plague" was for all disciplinary projects - a dream situation, "a dream about a disciplined society".

Surveillance capitalism is a large-scale process of collecting, analyzing and processing data for profit. Its essence is the constant gathering by large tech companies of "behavioral surpluses", i.e. traces from searching and browsing history of the websites by users. Each 'like', logging time to an app, time and place of shopping (not only online), voice search, all this information (and all the rest of our online activity ) are registered. Then, these data are subjected to predictive analysis - the process of extracting information from existing data sets. Its purpose is to define patterns and predict future events and trends. Surveillance capitalism transforms human experience into a free resource, which, as behavioral data, becomes "surveillance assets" transformed into surveillance capital. Man is exploited as sources of precious metal ores, with the difference that all fossil resources become depleted with time, while the 
current growth of the human population seems to be limitless (even the numerous pandemics in its history have not stopped this growth). Within surveillance capitalism, a person changes from client / consumer to client / resource. Capitalism itself is also taking a new shape. Production capitalism first evolves into "overproduction" capitalism (Deleuze 2015) to ultimately become surveillance capitalism thanks to the continuous development of technologies, especially digital ones. The owners of the means of production, who change into the owners of the "means of behavior modification", undergo a similar metamorphosis. Referring to Karl Polanyi and his concept of fictitious goods (Polanyi 2012), today's owners of surveillance capital announce the birth of the fourth fictitious product. Just like once lush meadows and forests, today such a virgin area for capital is the sphere of all our experiences. In the surveillance capitalism, not only human bodies are being exploited, but also thoughts and feelings. The encirclement of the body by the authorities is not anymore overwhelming, persistent and meticulous, as was the case from the eighteenth to the mid-twentieth century. Since the end of the 1960s, impressive disciplinary regimes such as schools, hospitals, barracks, housing estates, and families have been gradually softening, which does not mean that control and surveillance are disappearing, but that their form becomes more subtle (Foucault 2013: 348). Surveillance capitalism does not need instruments of direct discipline. Surveillance capitalism is not afraid of the rebellion of modern proletarians once they realize that they are treated by capital as nothing more but a unified mass devoid of individuality beyond the diverse ability to increase the value of capital (Arrighi 1990: 93-94). This is because surveillance capitalists saw in commodity work, in addition to the ability to increase the value of capital, also the potential of people's conviction of their individuality and autonomy. Speaking in the language of Foucault - surveillance capitalism can thoroughly examine what body is needed by the current society (Foucault 2013: 348), and then anticipate and program its further needs.

Because of the coronavirus outbreak, the direct relation between biological aspects of life and political interventions is in its peak (Esposito 2020). The same applies to biological life subject to the supervision of capitalist regime. The only difference is in the techniques of achieving the goals. Governments use direct disciplinary procedures, which in the case of a pandemic is manifested, inter alia, by the militarization of areas affected and the pursuit of a state of emergency. The consequence of such actions, which may turn out to be the norm in the post-pandemic world, may be a permanent change of political procedures of democratic states to procedures which are norms in authoritarian states (Agamben 2020). The question may be asked, how can democracy function if a citizen cannot? This, what in the name of security, political power does during a pandemic to weaken the functioning of a democratic society, surveillance capitalism began to practice long before its outbreak. The 'means of behaviors modification' of surveillance capitalism are a threat to personal freedom, and in the same time, they weaken democracy. Without autonomy in action and thinking, the ability to evaluate moral and critical thinking disappears, which is a sine qua non condition for a democratic society. Surveillance capitalism represents a new type of power which, unlike governments, operates remotely, using subliminal guidance engineering, social 
comparison dynamics, rewards and punishments, as well as a variety of enforcers who shape behaviors consistent with its commercial interests (Zuboff 2020).

Surveillance capitalism is a completely new force in socio-economic history, and although we already know well the mechanisms that it operates with - it is based on tremendous contempt for social norms and laws (Zuboff 2020) - and we have no clue what its legacy will be. Industrial capitalism, whose legacy is climate change, developed at the expense of nature, while surveillance capitalism developed at the expense of human nature. We can only hope that in the post-pandemic world these costs will not be as high.

\section{WORK IN POST-PANDEMIC WORLD}

Each crisis is like a magnifying glass which makes more visible contradictions of the social and economic status quo. The financial breakdown of 2008 revealed the weaknesses and contradictions of modern capitalism. It was after 2008 that books such as The Capital in the Twenty-First Century (Piketty 2013), Post Capitalism: A guide to our future (Mason 2015), or Utopia for realists. And how we can get there (Bregman 2017), and many similar were published. Although written from a bit different perspective and on various topics, they all embrace the criticism of modern capitalism and the belief that the recent crisis has opened a window to a new social and economic order.

Alongside with those ideas, the significant social and demographic changes have occurred. Richard Florida, in his The rise of the creative class, describes the emergences of a new social class, creative specialists, who, according to him, play the predominant role it the modern economy. In his study, he presents the set of values shared by the creatives, which highly influence their working style:

- opportunities to learn and grow

- quality of manager

- quality of management

- interest in type of work

- opportunities for advancement (Florida 2010).

The way the American theorist pictures this new class is similar to what sociologists see in the Y generation. Millennials, how some authors also describe them, include people born between 1980 and 2000. According to several studies, this generation is focused on self-fulfillment and satisfaction. Other core values, especially visible in the working environment, include respect, recognition, continuous development, fairness, tolerance, and equity (Sonnet, Kralj, and Kandampully 2012). Regardless of the label, sociologists agree that this generation is not mainly money-driven and that above mentioned values play more significant role to them in a workplace than the height of their salary (Florida 2012). To better understand this phenomenon, let us recall here the famous World Values Survey of Ronald Inglehart. What we know from 
his study, is that generations raised in welfare are less willing to make trade-offs and sacrifice their individual autonomy for the sake of economic and physical security. They take this security for granted and focus on being self-fulfilled and living up to their values (Inglehart 1977).

Since companies do not leave in a void, they naturally started looking for a new way of managing and organizing. It is important here to underline, that our attention was focused on the 'creative class' sector, so, obviously, a very privileged one. However, the choice was not random, as nowadays organizations operating in these certain economic and social structures have been searching for (and have been forced to by the employee market) implementing new management and work organization models.

The new organization ways which we will discuss here are variations of a broader concept of humanistic management. Humanistic management can be described as a trend that places people at the center. Humanistic approach to management was expressed very accurately by Emilian Orzechowski:

If we assume that the basic motive (and sense) of activity in any sphere of social life is to act for the good of man and the human groups that create this structure, bringing the essence to an economic dimension is total nonsense. (Kostera 2016)

It must be remembered, however, that classical management does not stand, or at least should not, in contradiction with humanistic management. What we are talking here about is the restoration of the main role in the organization of an employee. Monika Kostera (2016), one of the most important propagators of humanistic management in Poland emphasizes that thinking in economic terms is important not only from the point of view of the generated profit, but also for achieving goals of the general social dimension (such as providing jobs). This is an obvious reference to Adam Smith, who in the Theory of moral feelings postulates the use of reason not only for getting rich, but above all for respecting moral principles (Smith 1989). Quoting again Monika Kostera (2014),

This trend (humanistic - K.K) has three fundamental aspects. First of all, the goal of humanistic management is man (...). Secondly, humanistic management uses the legacy of the broadly understood humanities, understood as knowledge, culture and sensitivity. (...) Thirdly, humanistic management deals with human experience.

In this sense, humanistic management is very much aligned with the concept of sustainable development, as a compromise between the economic and social factors.

Let's have a closer look at two popular new management models, which are part of the humanistic shift.

(1) Agile management - agile management is a methodology, which has its source in software development. In 2001, seventeen developers published Agile Manifesto, with an aim to improve and ease software engineering processes. It is based on four core values, and twelve principles. The agile set of values is composed of the following:

a) Individuals and interactions over processes and tools. 
b) Working software over comprehensive documentation.

c) Customer collaboration over contract negotiation.

d) Responding to change over following a plan. (Web-02)

Jurgen Apello, in his Management 3.0, summarizes agile development in these words: "Agility is about staying successful in ever-changing environments" (2011: 376). Even though agility as a concept dates before 2008, as a broader management methodology has been gaining popularity in the recent decade.

(2) Holocracy: is a method of decentralized management and organizational governance, in which authority and decision-making are distributed throughout a holarchy of self- organizing teams, as opposed to the traditional, hierarchical systems. It based on the principles of flat hierarchy and self-governance (Web-03).

"Corona crisis" has occurred in the above described reality - in the times of social and economic changes that are results of the previous financial breakdown. This current pandemic will be a great test to the new management models. Are they able to practice what they preach?

Many of the creative class sector companies promise fulfillment, flexibility, development, and freedom. However, still before the pandemic crisis, the reality has been often far from that. According to the Gallup's study, only $10 \%$ of the adult fulltime employees are satisfied with their job. Also, the same number of working people are engaged in what they do. Most of them fulfill the orders with no mental nor emotional engagement in their tasks (Web-04). Many of the companies with the new management models actually offer to employees, what David Graeber called bullshit jobs. Those jobs, contrary to what they promise are alienating, and employees are forced to constantly work over-time for the reason of falsely understood engagement and flexibility (Graeber 2018). The corona era is going to be a great test for these models. It's a perfect time (due to mostly remote work) to finally give employees these stated: trust, freedom, flexibility. However, it can also reveal the weaknesses of many organizations and concepts, which instead will use new technology to obsessively control and deprive the employees from independence and security. It is obviously too early to know how the situation will evolve for the creative class. This is a preliminary analysis, and we need time to conduct a longtime research.

\section{SUMMARY}

History has repeatedly shown that outbreaks of new epidemics have always been associated with profound socioeconomic changes - according to some commentators, the appearance of the coronavirus is the end of the End of History (Jones 2020). Certainly, the current epidemic crisis will lead to many changes, including with high probability changes in models of political governance, social relations and labor relations. It is difficult to predict how (and if at all) the goals of sustainable development will be achieved in the new global order, but it will face the same change that has taken place in social, economic and environmental space. It will be a test of whether global justice 
and responsibility will still be possible under the new conditions (Ciążela 2006, Kuzior 2006, Harrari 2020). The most important thing is that the only alternative in the post-pandemic world would not be our regression to survivalist violence or barbarism with human face (Zizek 2020). Maybe it is enough for us to start thinking and valuing beyond the conditions imposed by capitalism. And this is not about throwing the shackles of capitalism just to get into a communism, but that in a Kantian way humans would always constitute ends in themselves for each other.

FUNDING: This research received no external funding.

CONFLICT OF INTEREST: The authors declare no conflict of interest.

\section{REFERENCES}

Agamben, Giorgio. 2020. “The Invention of an Epidemic.” Retrieved March 30, 2020 (https://www.quodlibet.it/giorgio-agamben-l-invenzione-di-un-epidemia).

Apello, Jurgen. 2011. Management 3.0. Leading Agile Developers. Developing Agile Leader. Boston: Addison-Wesley.

Arrighi, Giovani. 1990. “The Rise and Fall of Full Employment Capitalism.” Studies in Political Economy 4 (Autumn): 5-39.

Bregman, Rutger. 2017. Utopia for Realists: And How We Can Get There. London: Bloomsbury Publishing.

Ciazela, Helena. 2006. Problemy i dylematy etyki odpowiedzialności globalnej. Warszawa: Wydawnictwo Akademii Pedagogiki Specjalnej im. Marii Grzegorzewskiej.

Deleuze, Gilles. 2006. “Postscriptum o społeczeństwach kontroli.” Retrieved March 26, 2020 (http://www.ekologiasztuka.pl/articles.php?article_id=46).

Esposito, Roberto. 2020. “Cured to the Bitter End.” Retrieved March 29, 2020 (https:// antinomie.it/index.php/2020/02/28/curati-a-oltranza/).

Florida, Richard. 2012. Narodziny klasy kreatywnej. Warszawa: Narodowe Centrum Kultury.

Foucault, Michel. 1998. Nadzorować i karać. Narodziny więzienia. Warszawa: Alatheia.

Foucault, Michel. 2013. Kim pan jest, profesorze Foucault? Debaty, rozmowy, polemiki. Kraków: Eperons-Ostrogi.

Graeber, David. 2018. “On the Phenomenon of Bullshit Jobs: A Work Rant.” Retrieved March 30, 2020 (strikemag.org/bullshit-jobs).

Harari, Yuval N. 2020. “The world after coronavirus.” Retrieved March 30, 2020 (https:// www.ft.com/content/19d90308-6858-11ea-a3c9-1fe6fedcca75).

Inglehart, Ronald. 1977. Culture Shift in the Advanced Industrial Societies. New Jersey: Princeton University Press.

Jones, Lee. 2020. “Coronavirus Is the End of the End of History.” Retrieved March 30, 2020 (https://tribunemag.co.uk/2020/03/coronavirus-is-the-end-of-the-end-of-history?fbclid=IwAR1hSQzFE9MIibxy2I6yuo_aJlhFRqJLxf-WjZ9sW-QGfYF_oH9AGITerAg).

Kostera, Monika and Beata Glinka. 2016. Nowe kierunki w organizacji i zarządzaniu. Or- 
ganizacje, konteksty, procesy zarządzania. Warszawa: Wolters Kluwer.

Kuzior, Aleksandra. 2006. “Człowiek jako racjonalny podmiot działań w świetle załozeń koncepcji zrównowazonego rozwoju.” Problemy Ekorozwoju 1(2): 67-72.

Mason, Philip P. 2015. Post Capitalism: A guide to our future. London: Penguin.

Piketty, Thomas. 2015. Kapitał w XXI wieku. Warszawa: Wydawnictwo Krytyki Politycznej.

Polanyi, Karl. 2011. Wielka transformacja. Warszawa: Wydawnictwo PWN.

Smith, Adam. 1989. Teoria uczuć moralnych. Warszawa: PWN.

Zizek, Slavoj. 2020. "Biggest threat Covid-19 epidemic poses is not our regression to survivalist violence, but BARBARISM with human face.” Retrieved March 30, 2020 (https://www.rt.com/op-ed/483528-coronavirus-world-capitalism-barbarism/).

Zuboff, Shoshana. 2019. The Age of Surveillance Capitalism: The Fight for a Human Future at the New Frontier of Power. New York: PublicAffairs.

Zuboff, Shoshana. 2020. “Surveillance Capitalism.” Retrieved March 27, 2020 (https:// www.project-syndicate.org/onpoint/surveillance-capitalism-exploiting-behavioral-data-by-shoshana-zuboff-2020-01).

Web-01. 2020. "The age of surveillance capitalism : the fight for a human future at the new frontier of power.” Retrieved March 31, 2020 (https://www.consilium.europa.eu/pl/documents-publications/library/library-blog/posts/the-age-of-surveillance-capitalism/).

Web-02. 2018. “Manifesto for Agile Software Development.” 2018. Retrieved March 30, 2020 (agilemanifesto.org).

Web-03. 2020. "Why practice holacracy.” 2018. Retrieved March 30, 2020 (https:// www.holacracy.org/explore/why-practice-holacracy)

Web-04. 2020. “Gallup.” 2018. Retrieved March 30, 2020 (www.gallup.com).

\section{BIOGRAPHICAL NOTE}

Łukasz Rąb, doctor of philosophy, adjunct in Department of Philosophy and Sociology at The Maria Grzegorzewska University. The author's main areas of scientific research are the modern forms of capitalism, i.e. "surveillance capitalism" or "ecological capitalism", as well as the topic of the evolution of work during the digital revolution and problems that it implies, such as "precarization of life" and "uberization of work".

Karolina Kettler is an adjunct in the Department of Applied Social Sciences of Silesian University of technology. In her scientific research, she focuses on the topics of work, organization, organizational culture, recruitment and personnel management.

OPEN ACCESS: This article is distributed under the terms of the Creative Commons Attribution Non-commercial License (CC BY-NC 4.0) which permits any non-commercial use, and reproduction in any medium, provided the original author(s) and source are credited.

ARTICLE HISTORY: Received 2020-03-31 / Accepted 2020-04-06 